\title{
Three Poems on Ageing
}

\author{
Translated by Nathan Sivin \\ for Theodore Friend's \\ eightieth birthday, $2011^{1}$
}

\section{Losing Teeth, by Han Yu, 803?}

I lost a tooth last year, lost a tooth this year, ${ }^{2}$

Lost, all of a sudden, six or seven. Looks like it's not over.

All the rest are loose, in the end they'll all fall out.

I recall when I lost the first, the gap shamed me;

After losing two or three, I thought I was far gone.

When one was about to fall out, I always blamed myself.

With them in disarray, it was hard to eat, so jumbled I feared to rinse them.

When finally one abandoned me, it was bad as a mountain falling in.

By now I'm used to it; when they're lost they're all the same.

Twenty or so left, but they'll fall out in their turn.

If one's lost every year, they'll last a couple of decades; ${ }^{3}$

Once all are lost, does it matter, fast or slow?

People say when your teeth are lost you can't expect to live long;

I say life always has its limit-long or short, we die.

People say gaps in your teeth scare those who look;

I say, like Master Zhuang, what's useless at least survives. ${ }^{4}$

1 Theodore Friend is an American scholar of Islam, especially that of Indonesia and the Philippines, former President of Swarthmore College, and former President of the Eisenhower Foundation.

2 These two verses use different graphs, ya 牙 and $c h i$ 齒, which together make up the most common word for tooth. Some eminent authorities give different meanings for the two-for instance, molar and incisor, or front and back tooth. Here they are evidently synonyms.

3 The word Han uses is $j i$ 紀, a cycle of 12 years.

${ }^{4}$ Literally, 'the tree and the goose had something to be happy about' alluding to an anecdote in Zhuangzi 莊子 (51/20/2). Master Zhuang was walking in the mountains when he saw a huge tree, its branches and leaves thick and lush. A woodcutter paused by its side but made no move to cut it down. When Master Zhuang asked the reason, he replied, 'There's nothing it could be used for!' Master Zhuang said, 'Because of its worthlessness, this tree is able to live out 
When you can't talk clearly, silence is quite all right; when you can't chew, soft food has its charm.

So my song has become a poem, to shock my wife and children.

\section{落齒}

去年落一牙，今年落一齒。

俄然落六七, 落勢殊未已。

餘存皆動搖, 盡落應始止。

憶初落一時, 但念豁可恥。

及至落二三，始憂衰即死。

每一將落時, 檩檩恒在已。

叉牙妨食物，顛倒怯漱水。

終焉舍我落, 意與崩山比。

今來落既熟，見落空相似。

餘存二十餘，次第知落矣。

倘常歲落一, 自足支兩紀。

如其落並空，與漸亦同指。

人言齒之落, 壽命理難恃。

我言生有涯, 長短俱死爾。

人言齒之豁, 左右驚諦視。

我言莊周雲, 水雁各有喜。

語叱默固好，嚼廢軟還美。

因歌逐成詩，持用詫妻子。

\section{Comment}

Han Yu 韓愈 (768-824) is best known as a shaper of prose style, but he was a key figure in every field of literature - and, as a statesman, in politics as well. This poem is a splendid example of one kind of innovation among his many kinds. It is conversational and informal. Not only is its language closer to

the years Heaven gave it'. Down from the mountain, the Master stopped for a night at the house of an old friend. The friend, delighted, ordered his son to kill a goose and prepare it 'One of the geese can cackle and the other can't', said the son. 'May I ask, please, which I should kill?' 'Kill the one that can't cackle', said the host. The next day Master Zhuang's disciples questioned him 'Yesterday there was a tree on the mountain that gets to live out the years. Heaven gave it because of its worthlessness. Now there's our host's goose that escapes getting killed because of its worthlessness...'. 
speech than that of his predecessors, but the repetition of the word luo, 'to fall out, to lose' in one line after the other is striking.

This poem is from Han Changli shi xinian ji shi 韓昌黎詩繫年詩集 (Poetry of Han Yu, chronologically arranged, with critical notes; Shanghai: Gudian Wenxue Chubanshe, 1957), 2: 81-2. It was probably written in 803, when Han was only 35 . He often remarked on the state of his teeth in poems he wrote to friends in that period of his life. A poem of 812 tells us that at the age of 44 he had a little over ten teeth left; his estimate of a tooth to be lost a year was—up to that point—rather accurate (ibid., 8: 369).

Laments over the loss of teeth, and generally over early ageing, were common among scholar-officials, who despite their prestige led hard lives during their endless travels. Rinsing the mouth and brushing the teeth (usually with a willow twig) was common, but dentistry was not a highly developed part of medicine anywhere before modern times. As in Europe, it was easier to find someone to pull teeth than to preserve them.

\section{My Eyes Grow Dim, by Bai Juyi, 814}

In my early years, reading too much, I suffered,

In later years, pain drew from me many tears.

Unaware my eyes were hurt, I took them for granted.

When they were really ill, I knew it-what could I do?

Dusk coming on: like a lamp going black;

Morning so dark: like an unpolished mirror.

A thousand medicines, myriad formulas, can't cure it.

All that is left is to close my eyes and learn to shake off the dust. ${ }^{5}$

\section{眼暗}

早年勤倦看書苦，晚歲悲傷出淚多。 眼損不知都自取, 病成方悟欲如何。 夜昏乍似灯将滅, 朝闇長疑鏡末磨。 千藥萬方治不得, 唯應閉目学頭陀。

5 Toutuo 頭陀 is the Chinese way of writing Sanskrit dhūta, 'shaking off', used by Buddhists for meditation and other disciplines that overcome obstacles to enlightenment (and sometimes used for monks dedicated to those disciplines). Bai used the term often. 


\section{Comment}

Bai Juyi 白居易 (772-846) was among the greatest poets of China. When he wrote this poem, he was only 42 , but his health was poor. His failing vision was a topic of many poems in his huge output over a long life. This is perhaps the earliest, and reads best in translation.

The point of this brief poem goes beyond his worry about his eyesight. The last two lines express it. Although as a high official, Bai had access to the best physicians of his time, medicine had failed to halt the deterioration. The only solution left was meditation and other Buddhist disciplines that promised to end all suffering through enlightenment, 'shaking off the dust'.

From Bai's poetry collection, Chang qing ji 長慶集 (in Siku quanshu), 14: $16 a$.

\section{On Ripe Old Age, by Zhu Dunru, before 1175}

As I grow old I enjoy it. I've been everywhere, Known what lies beyond, Seen through nothingness.

For a time I've crumpled up Oceans of regret, mountains of grief.

I don't let the flowers fuddle me, Wine doesn't daze me,

Alert wherever I go. A good dinner, a place to sleep;

Awake once more, I mount the stage to play my part.

Don't tell me the past is gone, today is here.

In an old man's heart there's not that much to think about.

Nor do I pray to the saints, beseech the Buddha,

Not bustling about like Confucius,

Too lazy to argue with the right-thinkers.

Let them laugh — this is how it is.

When the comedy is over,

I'll take off my costume and hand it to the boobies.

老来可喜，是力遍人間，諳知物外。

看透虚空, 将恨海愁山, 一時挼碎。

免被花迷, 不為酒困, 到處惺惺地。

跑来覓睡，睡起逢場作戲。

休說古徍今来，局翁心里，没許多般事。

也不龩仙不传佛, 不学栖栖孔子。 
懶共賢争, 从教他笑, 如此只如此。

雜劇打了, 戲衫脱与呆底。

\section{Comment}

Despite the impression this poem gives of a life involved in great affairs, Zhu Dunru 朱敦儒 (1080 or 1081 to $c a$. 1175), although he came of a scholarofficial family, did not strive to become a civil servant. He was a hermit poet and painter until, at the age of 55, on the basis of his poetic talent, he was unexpectedly awarded official rank and summoned to court. He spent a couple of decades there, first as an official of middling rank and then as a teacher of poetry and painting. After retirement, in his last 20 years, he was surrounded by disciples, living away from the capital-but not very far away. From Kui ye ji 葵嘩集, Bloomington: Indiana University Press, 1976, p. 160.

\section{Comment on All Three Poems}

It is interesting and ironic that the first two poems, which are eloquent about the dilapidation of their authors, were written by men who had not yet reached 45 , and who lived on to considerable ages. The third, on the other hand, by someone near the end of his very long span of life, shows no concern about physical ageing. His cheerfulness perhaps comes from living long enough to accept that sadness does not rule out joy. 